San Jose State University

SJSU ScholarWorks

Faculty Publications, Biological Sciences

Biological Sciences

April 2011

\title{
Geographic Variation in Temperature Tolerance as an Indicator of Potential Population Responses to Climate Change
}

\author{
Cascade J.B. Sorte \\ Northeastern University \\ Sierra J. Jones \\ University of South Carolina - Columbia \\ Luke P. Miller \\ Northeastern University, luke.miller@sjsu.edu
}

Follow this and additional works at: https://scholarworks.sjsu.edu/biol_pub

Part of the Biology Commons

\section{Recommended Citation}

Cascade J.B. Sorte, Sierra J. Jones, and Luke P. Miller. "Geographic Variation in Temperature Tolerance as an Indicator of Potential Population Responses to Climate Change" Journal of Experimental Marine Biology and Ecology (2011): 209-217.

This Article is brought to you for free and open access by the Biological Sciences at SJSU ScholarWorks. It has been accepted for inclusion in Faculty Publications, Biological Sciences by an authorized administrator of SJSU ScholarWorks. For more information, please contact scholarworks@sjsu.edu. 
3

4

5

6

\title{
Geographic variation in temperature tolerance as an indicator of potential population
} responses to climate change

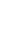

\author{
Cascade J. B. Sorte ${ }^{\mathrm{a}^{*}}$, Sierra J. Jones ${ }^{\mathrm{b}}$, and Luke P. Miller ${ }^{\mathrm{a}}$
}

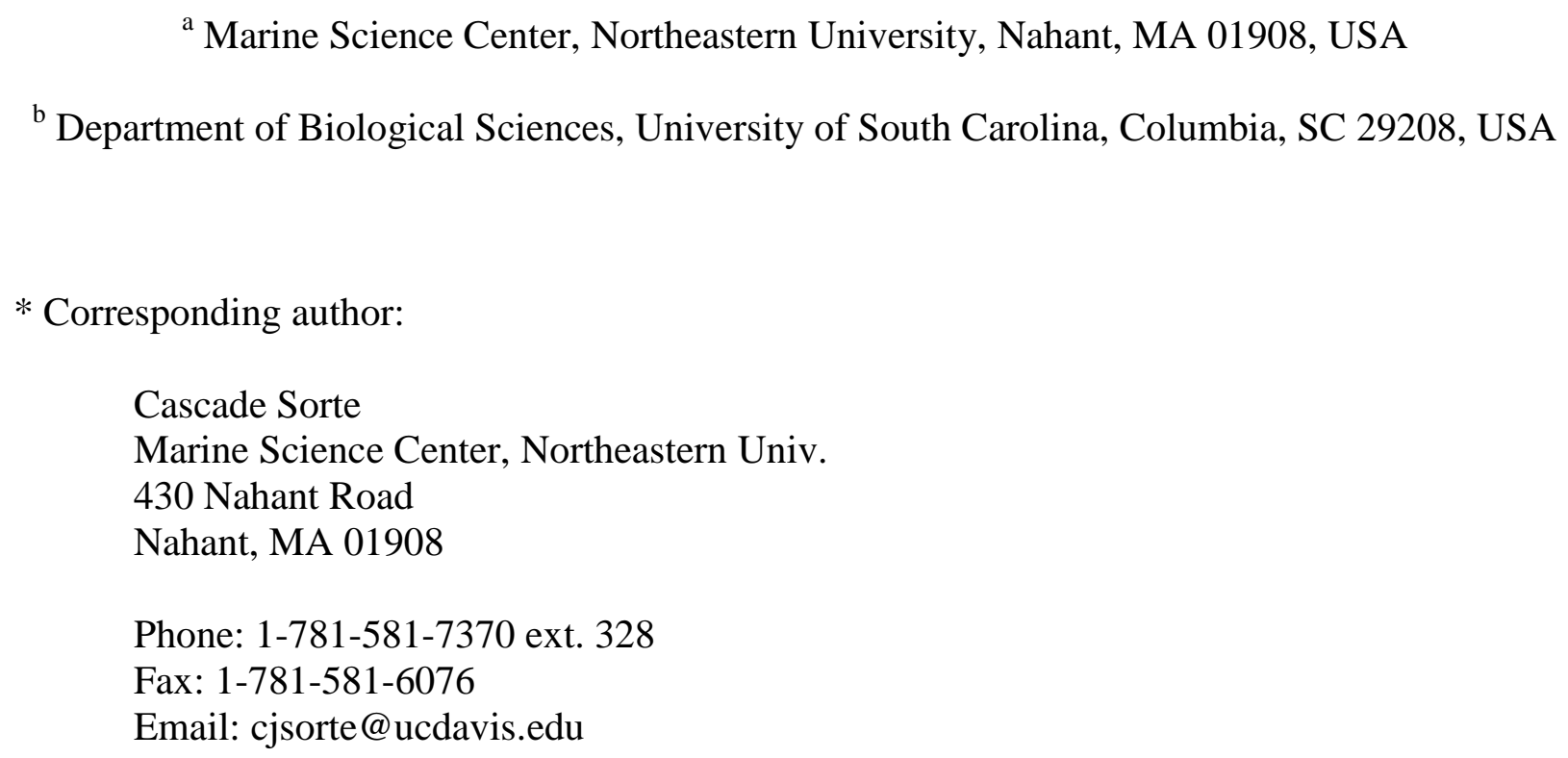

* Corresponding author:

Cascade Sorte

Marine Science Center, Northeastern Univ.

430 Nahant Road

Nahant, MA 01908

Phone: 1-781-581-7370 ext. 328

Fax: 1-781-581-6076

Email: cjsorte@ucdavis.edu

Author email addresses: cjsorte@ ucdavis.edu (Cascade Sorte), sierra.jenell.jones@ gmail.com (Sierra Jones), contact@lukemiller.org (Luke Miller)

2

4 Keywords: Acclimatization, Biogeography, Climate change, Ecological forecasting, Ecophysiology, Temperature tolerance 


\section{Abstract}

The temperature tolerances of individuals in geographically separated populations of a

29 single species can be used as indicators of each population's potential to persist or become extinct in response to climate change. We evaluated the population-level variation in temperature tolerance in populations of several marine invertebrate taxa, including bryozoans, tunicates,

32 bivalves, and gastropods, separated by distances of $<200 \mathrm{~km}$ to $>5,000 \mathrm{~km}$. We then combined physiological thermotolerance data with current temperature data and climate change predictions to predict which of these populations may be most vulnerable to future changes. In a transcontinental comparison of four subtidal epibenthic species, we show that populations on the east coast of the United States, which experienced higher habitat temperatures than those on the west coast, had higher thermal tolerances but lived closer to individuals' tolerance limits. Similarly, temperature tolerances varied between western and eastern Atlantic populations of the mussel Mytilus edulis; however, these differences only emerged after repeated exposures to high temperatures. Furthermore, the less thermotolerant M. edulis population in the western Atlantic was more susceptible to temperature increases, as evidenced by a recent range contraction. Thus,

42 for both the subtidal epibenthic and intertidal mussel species, we identified the western Atlantic 43 as a 'hot spot' of populations susceptible to climate change compared to those in the eastern 44 Pacific and eastern Atlantic, respectively. Finally, because current tolerances are not the sole indicators of individuals' abilities to cope with temperature increases, we also assessed the 46 possibility for acclimatization to facilitate the persistence of populations via the buffering of 47 temperature effects. We show that, for four populations of intertidal Littorina snail species in the 48 northwest Atlantic, most populations were able to overcome geographic differences in temperature tolerance via acclimation. When acclimation capacity is low, the potential for 
50 "rescue" may depend on the particular species' life-history strategy and dispersal ability. For

51 example, although individuals from the coldest-adapted population of Littorina littorea were

52 unable to acclimate as quickly as those from more southern populations, this species has a

53 pelagic larval stage and, thus, the greatest dispersal potential of these littorines. Together, these

54 studies highlight the importance of considering variation in temperature tolerance between

55 populations within species to improve the forecasting of changes in the abundances and

56 distributions of species in response to climate warming.

57

\section{Introduction}

As mean and extreme temperatures increase in marine systems, the likelihood that a

60 given population persists is partly related to the physiological capacity of organisms to tolerate

61 elevated temperatures (Hutchins, 1947; Newell, 1969; 1979). Temperature clearly affects

62 species' distribution patterns: a strong relationship between upper temperature tolerance and maximum habitat temperature has been demonstrated for many species (Wolcott, 1973;

64 Tomanek and Somero, 1999; Stillman and Somero, 2000; Stillman, 2002; Wethey, 2002; Miller et al., 2009; Lockwood \& Somero, 2011, this volume). Shifts in species' ranges have been linked to rising mean temperatures (Southward et al., 1995; Herbert et al., 2003; Mieszkowska et al.,

67 2005; Helmuth et al., 2006; Wethey and Woodin, 2008; Sorte et al., 2010a; Poloczanska et al.,

68 2011, this volume). Furthermore, increases in extreme temperatures have been followed by

69 mortality events (Garrabou et al., 2009; Firth and Williams, 2009; Jones et al., 2009, 2010;

70 Marbà and Duarte, 2010). Recent studies have focused on interspecific differences in

71 temperature tolerance - particularly between closely-related congeners - to identify organismal

72 and ecological characteristics of the "winners" and "losers" of climate change (Somero, 2010). It 
73 has been suggested that species with higher temperature tolerances will be better able to cope

74 with global warming (Calosi et al., 2008) or, conversely, that more warm-adapted species will be 75 at a disadvantage because they tend to live closer to their absolute tolerance limits (Stillman and 76 Somero, 2000; Somero, 2005, 2010; Compton et al., 2007; Bonebrake and Mastandrea, 2010) 77 and have lower acclimation potentials (Stillman, 2003; Somero, 2005; Stenseng et al., 2005; 78 Ghalambor et al., 2006). In this paper, we treat these hypotheses by taking a more intimate look 79 at geographic variation in temperature tolerance within species, including its potential as an 80 indicator of regions likely to experience local extinction or population persistence.

81 Geographic variation in temperature tolerance, or differences in the average individual 82 tolerances between geographically distinct populations, arises due to individual variation. This 83 variation in temperature tolerance of an organism represents both adaptation (a distinct genotype) 84 and phenotypic plasticity, or the range of phenotypes possible for a single genotype, which can 85 be either fixed or variable over an individual's lifespan. Most studies examining geographic 86 variation in thermal tolerance have focused on differences along a latitudinal gradient, including 87 studies designed to test and explain Rapoport's rule (that latitudinal range size increases with 88 latitude; Addo-Bediako et al., 2000) and Janzen's hypothesis (that mountain passes - as abrupt 89 environmental breaks - are physiologically 'higher' for stenothermal, warm-adapted tropical 90 species; Janzen, 1967; Ghalambor et al., 2006). At the species level, latitudinal distribution is 91 often positively related to thermal tolerance range, although the implications for responses to 92 climate change are equivocal given that this pattern is often driven by greater variation in lower, 93 rather than upper, tolerance limits (Goto and Kimura, 1998; Gaston and Chown, 1999; Addo94 Bediako et al., 2000; Kimura, 2004). 
Here, we consider geographic variation in the upper limit of temperature tolerance in the context of predicting population-level responses to climate change. Populations likely to persist

97 in the warmer conditions predicted with climate change are those in which, as diagrammed in

98 Fig. 1: (i) individuals have high temperature tolerances, (ii) individuals have the capacity, via

99 phenotypic plasticity, to acclimate to higher temperatures, or (iii) populations of tolerant

100 individuals - those that either already have high tolerance or have high acclimatization capacity

101 - can disperse and re-seed areas of less tolerant populations (Deutsch et al., 2008). Thus,

102 populations that are more prone to local extinction will be those in which individuals have low

103 temperature tolerance, low acclimatization capacity, and/or low dispersal ability (Deutsch et al.,

104 2008). We present three case studies in which we combine physiological thermotolerance data

105 with current temperature data and climate change predictions. By examining ecophysiological

106 and biogeographic patterns for a diverse set of marine taxa - including bryozoans, tunicates,

107 bivalves, and gastropods - we provide a starting point for addressing broad questions about

108 climate-change impacts relevant to many systems, both marine and terrestrial, such as:

109 (1) How do temperature tolerances vary geographically over small (i.e. regional) and large (i.e. 110 trans-continental and trans-oceanic) scales?

111 (2) Are populations with higher average temperature tolerances likely to be at an advantage due 112 to their capability of surviving at increased temperatures or at a disadvantage due to a narrower 113 distance between their tolerance limits and projected temperature exposures?

114 (3) Do more tolerant populations possess the acclimation capacity and dispersal potential that 115 could "rescue" vulnerable populations from local extinction? 
Populations separated by continents or ocean basins exchange propagules only rarely and may, thus, exhibit marked variation in acclimatization and adaptation of temperature tolerance (e.g. see Vellend et al., 2007). We determined the upper $\mathrm{LT}_{50}$, or temperature lethal to $50 \%$ of individuals in the population, for four epibenthic species collected in Massachusetts (USA; on the east coast) and compared these values to those for individuals collected in California (USA; on the west coast).

\subsection{Methods}

In July and August 2010, four epibenthic species settled naturally onto plastic tiles (Duplos; LEGO Group, Billund, Denmark) deployed in marinas at approx. $1 \mathrm{~m}$ depth. The tunicates Botrylloides violaceus and Botryllus schlosseri were collected on tiles deployed at Lynn, Massachusetts $\left(42.4577^{\circ} \mathrm{N}, 70.9434^{\circ} \mathrm{W}\right)$, and the tunicate Diplosoma listerianum and bryozoan Bugula neritina were similarly obtained at Hawthorne Cove Marina in Salem, Massachusetts $\left(42.5195^{\circ} \mathrm{N}, 70.8872^{\circ} \mathrm{W}\right)$. West coast individuals were collected at Bodega Harbor, California $\left(38.3311^{\circ} \mathrm{N}, 123.0567^{\circ} \mathrm{W}\right)$ in July and August 2009.

Lethal temperatures were determined following the methods detailed in Sorte et al. (2010b, for the west coast individuals) with exceptions as noted below. Briefly, individuals were acclimated in the laboratory in running seawater at ambient temperature (approx. $17^{\circ} \mathrm{C}$ ) for $24 \mathrm{~h}$, after which tiles containing 2 individuals (colonies) of a single species were placed in separate $1 \mathrm{~L}$ experimental chambers (note: one individual per chamber was used for B. neritina when necessary due to low recruitment). Temperature was raised at a rate of $1{ }^{\circ} \mathrm{C}$ per 5 min until the treatment temperature was reached, and mortality was assessed following a $24 \mathrm{~h}$ temperature exposure (at approx. $21,25,29$, and $34^{\circ} \mathrm{C}$; actual chamber temperatures were used in the analyses). LT $_{50}$ values were calculated by Probit analysis in SAS v 9.1 (SAS Institute, Cary, 
141 North Carolina, USA) and were compared to values for west coast populations determined in 142 July and August 2009 (Zerebecki and Sorte, in review).

143 Projected temperature changes for the east and west coast sites studied were calculated 144 from nine global circulation models available as part of the World Climate Research

145 Programme's Coupled Model Intercomparison Project 3 (CMIP3; Meehl et al., 2007). We 146 calculated changes in average monthly sea surface temperatures using the Intergovernmental 147 Panel on Climate Change SRES A1B emissions scenario (IPCC Working Group III, 2000). Data 148 from each climate model were processed in the program R v 2.11.1 (R Core Development Team, 149 2010) to extract the projected average monthly temperatures for the ocean grid cell closest to 150 each of our sites. We used temperature estimates from 1961-90 as a baseline for comparison 151 against the future projections for 2090-99. We calculated the mean temperature in each time 152 period (1961-90 and 2090-99) separately for each month (January - December) and used the 153 difference between the two time periods as our estimate of future temperature change for each 154 month of the year. The average temperature change for the entire year was calculated from the 155 monthly changes.

156 2.2. Results \& Discussion

157 Lethal temperatures were higher for east coast than west coast populations of all four 158 epibenthic species ( 1 -sample t-test: $t=6.1207$, df $=3, p=0.0088$; Fig. 2). The difference 159 between $\mathrm{LT}_{50}$ values for east and west coast populations ranged from $1.1^{\circ} \mathrm{C}$ for $\mathrm{B}$. schlosseri to $1602.1^{\circ} \mathrm{C}$ for $B$. violaceus. Absolute $\mathrm{LT}_{50}$ values (east/west coast) were $29.4 / 28.3^{\circ} \mathrm{C}$ for $B$. 161 schlosseri, $27.4 / 25.3^{\circ} \mathrm{C}$ for $B$. violaceus, $29.1 / 27.9^{\circ} \mathrm{C}$ for $D$. listerianum, and $26.4 / 24.4^{\circ} \mathrm{C}$ for 162 B. neritina. The magnitude of variation in temperature tolerance between east and west coast 163 populations was strongly related to the $\mathrm{LT}_{50}$ : species that were less thermotolerant on the west 
164 coast displayed a greater difference in $\mathrm{LT}_{50}$ between the east and west coasts $\left(F_{1,2}=25.92, p=\right.$ $\left.1650.0365 ; R^{2}=0.93\right)$.

Temperature tolerances also paralleled habitat temperatures. Mean summertime water temperature in Massachusetts was $2.4^{\circ} \mathrm{C}$ warmer than in California (June - August, 2006-2010), and annual temperature range was twice as broad -24.9 vs. $12.4^{\circ} \mathrm{C}-$ in the eastern USA (Fig. 3;

169 Sorte and Stachowicz, in review; MA data from NOAA National Buoy Data Center <www.nbdc.noaa.gov> Boston Harbor station BHB3M). The east coast populations are currently

171 living closer to individuals' summer tolerance limits: maximum summertime temperatures were

$1724.4^{\circ} \mathrm{C}$ higher in Massachusetts, and these local temperature maxima were within $3.9^{\circ} \mathrm{C}$ of

173 populations' $\mathrm{LT}_{50}$ values on the east coast but $6.7^{\circ} \mathrm{C}$ greater than those on the west coast. The 174 species living closest to its tolerance limit, the bryozoan Bugula neritina, encountered maximum 175 temperatures within $2.2^{\circ} \mathrm{C}$ and $4.6^{\circ} \mathrm{C}$ of its $\mathrm{LT}_{50}$ on the east and west coast, respectively.

If acclimatization and adaptation abilities do not vary between populations, then the east

177 coast populations will continue to be more susceptible due to expected increases in ocean

178 temperatures. When projected temperature increases are taken into account, summer (June 179 August) sea surface temperatures on the east coast are likely to approach or exceed the $\mathrm{LT}_{50}$ 180 values of the two species living closest to their tolerance limits, Bugula neritina and Botrylloides 181 violaceus, by the end of the 21 st century. In Massachusetts, mean summer and annual sea surface 182 temperatures are projected to rise by 3.0 and $3.3^{\circ} \mathrm{C}$, respectively. In California, mean increases of 1832.4 and $2.7^{\circ} \mathrm{C}$ are predicted for summer and annual sea surface temperatures, respectively, which 184 are still below the four species' $\mathrm{LT}_{50}$ values. However, for California populations of B. neritina 185 and B. violaceus, this increase in summer temperatures could nevertheless elicit 20-30\% mortality (Fig. 2). 
These data support, at the population level, the documented pattern that species living at

higher temperatures occur closer to their absolute tolerance limits (i.e. Stillman and Somero, 2000; Somero, 2005, 2010; Compton et al., 2007; Deutsch et al., 2008), and they suggest that east coast populations will be at a disadvantage in warmer conditions relative to west coast populations. This prediction, however, neglects these species' potentials for acclimatization and local adaptation, which may, if representative of genotypic variation, be indicated by two studies showing significant phenotypic variation over small distances. For example, Grosholz (2001) showed local adaptation in minimum temperature tolerance of Botrylloides sp. between sites separated by $<60 \mathrm{~km}$, and variation in habitat temperatures may have caused differences in Botryllus schlosseri population dynamics between sites only $<20 \mathrm{~km}$ distant (Yund and Stires, 2002). Such fine-scale population adaptation is possible for species that lack a pelagic larval stage and recruit extremely locally, such as the intertidal dogwhelk Nucella canaliculata (Kuo and Sanford, 2009) and the four epibenthic species treated here. Clearly, these epibenthic species have the potential for acclimatization and/or rapid local adaptation: all four are non-natives that were most, if not all, introduced to California during the past century (Cohen, 2005), and already there are apparent differences in temperature tolerance between east and west coast populations. Interestingly, the two least tolerant species also showed the greatest individual variation in temperature tolerance (as indicated by the shallower slope of their tolerance curves in Fig. 2) suggesting - if phenotypic variation indicates genotypic variation - that populations of these species have a greater potential for adaptation.

A comparison with previous research in the Bodega Harbor epibenthic community showed strong effects of age on survival rate and that the impacts of increased temperatures can be exacerbated - and even reversed - in older individuals. For example, a 3-day experimental 
210 heat wave of $24.5^{\circ} \mathrm{C}$ caused $100 \%$ mortality in adults of the three tunicate species considered

211 here but little to no mortality in adults of the bryozoan Bugula neritina (Sorte et al., 2010c),

212 which is the most susceptible of these species as a juvenile. Furthermore, on the west coast, $\mathrm{LT}_{50}$

213 values were lower for native species than for non-native species overall (Sorte et al., 2010b).

214 Thus, both on the east and west coasts, different life stages, and the respective suite of native 215 species, may be living more 'on the edge' in epibenthic communities.

\section{3. Marine mussels: a cross-ocean comparison}

$219<25^{\circ} \mathrm{C}$ annually and less on shorter (i.e. daily) timescales, the marine intertidal zone is a 220 physically rigorous habitat in which rapid and extreme fluctuations in temperature occur on a 221 daily basis. Mussels in the genus Mytilus are major space occupiers of marine intertidal habitats, 222 and, like tunicates and bryozoans, are sedentary. Because their responses to environmental 223 change are largely unmitigated by behavior, their upper intertidal and equatorward geographic 224 distributions are often constrained by physiological limits, such as thermal tolerance.

225 3.1. Methods

The upper thermal tolerance of the mussel Mytilus edulis was determined for western and 227 eastern Atlantic populations using the methods presented in Jones et al. (2009). Adult mussels 228 were collected from Nahant, Massachusetts, USA $\left(42.4195^{\circ} \mathrm{N}, 70.9023^{\circ} \mathrm{W}\right)$ on 20 June 2006 and

229 from Luc-sur-Mer, Normandy, France $\left(49.3110^{\circ} \mathrm{N}, 0.3555^{\circ} \mathrm{W}\right)$ on 5 July 2010 . Shell lengths

230 (mean $\pm \mathrm{SD}$ ) were $45.2 \pm 5.0 \mathrm{~mm}$ and $27.14 \pm 2.15 \mathrm{~mm}$ for the mussels from the USA and

231 France (FR), respectively. Upon collection, animals were transported in coolers to temperature232 controlled recirculating seawater tanks (“control” tanks: Living Streams; Frigid Units, Toledo, 
233 Ohio, USA) with a semidiurnal tidal cycle at the University of South Carolina (Columbia, South 234 Carolina, USA) and acclimated for one week.

235 Water temperature in the control tanks was maintained at approximate ambient field 236 temperatures of $18^{\circ} \mathrm{C}$ (USA) and $19^{\circ} \mathrm{C}(\mathrm{FR})$ for the duration of the experiment. Most thermal 237 tolerance experiments previously conducted on M. edulis examined the response to water 238 temperatures alone (Ritchie, 1927; Read and Cumming, 1967; Pearce, 1969; Rajagopal et al., 239 2005). However, because these intertidal mussels are exposed to both submerged and aerial 240 conditions, each experimental trial was run in both water and air at a range of environmentally 241 realistic temperatures, including $25,30,32.5,35$, and $40^{\circ} \mathrm{C}$, with three replicates of 5 animals for 242 each temperature treatment ( $n=15$ per temperature x medium treatment). Reach-in incubators 243 were maintained for the duration of the experiment at each of the target temperatures to within \pm $2440.25^{\circ} \mathrm{C}$. Aquaria $(38 \mathrm{~L})$ were placed inside the incubators, and in this manner both the air and 245 water treatments could be run simultaneously. The role of evaporative cooling in mussels (i.e. 246 gaping) was assumed to be negligible, as Fitzhenry et al. (2004) showed that mussel body 247 temperatures were not related to gaping ability.

Mussels were exposed to the same temperature for a $6 \mathrm{~h}$ period each day, simulating one 249 tidal event per day, and the experiment was run for 5 consecutive days as a means of discerning 250 the effects of thermal history. Following each exposure event, mussels were removed from the 251 incubators and returned to the respective control tanks (with tidal period) for a recovery period of $25218 \mathrm{~h}$, after which we counted the numbers of dead individuals. The recovery period simulated 253 natural conditions in which a period of stress is followed by an extended period of immersion 254 and/or a second emersion during the morning or night when air temperatures are relatively low. 255 Mussels from the air and water treatments were held in separate control tanks on opposing tidal 
256 cycles in order to ensure proper cycling of emersion and immersion periods. The $\mathrm{LT}_{50}$ values

257 were calculated for each exposure event by linear interpolation of the graphs of cumulative

258 survival versus temperature in R v 2.8.1 (R Core Development Team, 2010)

259 3.2. Results \& Discussion

Multiple exposures decreased temperature tolerances for both the USA and French

261 populations of M. edulis (Fig. 4). For both populations, there was a fast initial decline in

262 tolerance, and tolerance tended to plateau after the third exposure. The two populations tended to

263 diverge after the second exposure, and population differences in $\mathrm{LT}_{50}$ continued to increase

264 through the fifth exposure. By the fifth exposure, mussels from the French population of $M$.

265 edulis had thermal tolerances that exceeded those from the USA population by $4.5^{\circ} \mathrm{C}$ and $2.5^{\circ} \mathrm{C}$

266 in air and water, respectively. Thus, there was a common relationship between $\mathrm{LT}_{50}$ and number

267 of exposures for both populations, with thermal tolerance decreasing as a function of increasing

268 exposures. These findings indicate the importance of accounting for thermal history when

269 examining survival within an ecological context.

270 When $\mathrm{LT}_{50}$ values were averaged across the 5 exposures, tolerances were higher for FR

271 than USA mussels in both air (Welch Two-Sample t-test; $t=-2.776, \mathrm{df}=5.109, p=0.038$ ) and

272 water (Welch Two-Sample t-test; $t=-1.966, \mathrm{df}=7.846, p=0.086$ ). However, in this cross-ocean

273 comparison of $M$. edulis, differences in temperature tolerances did not parallel those in habitat

274 temperatures. Daily optimally interpolated sea surface temperature (OISST) data on a $0.25^{\circ}$ grid

275 (Reynolds et al., 2007) were obtained for the nearest pixel corresponding with collection sites for

276 the period January 1998-December 2008. There was little to no difference between USA and FR

277 locations in annual maximum ocean temperatures, which ranged from $19.6-22.7^{\circ} \mathrm{C}$ in $\mathrm{FR}$, with

278 an average maximum of $20.8^{\circ} \mathrm{C}$, and between $19.3-21.3^{\circ} \mathrm{C}$ in the USA, with an average 
279 maximum of $20.7^{\circ} \mathrm{C}$. Considering that an immersed mussel will have the same body temperature 280 as the water (Gilman et al., 2006), the differences in immersed thermal tolerances between the 281 two populations are surprising since maximum habitat water temperatures are similar.

282 Interestingly, the seasonal range in temperatures experienced was, on average, $4.3^{\circ} \mathrm{C}$ greater in 283 the USA/western Atlantic where the population is composed of less thermally tolerant 284 individuals.

The disconnection between habitat temperatures and thermal tolerances was even more 286 pronounced for air temperatures. Hourly air temperature data were obtained from the National 287 Climatic Data Center (www.ncdc.noaa.gov) for Boston, Massachusetts, USA (42.3584 ${ }^{\circ}$, $28871.0598^{\circ} \mathrm{W}$; Site ID: 725090$)$ and Cap de la Hève, France $\left(49.5167^{\circ} \mathrm{N}, 0.0667^{\circ} \mathrm{E}\right.$; Site ID: 289 070280) for the period January 1998 - December 2009. Annual average maximum temperature 290 for FR ranged between $29.4-36.1^{\circ} \mathrm{C}$, with an average maximum of $31.2^{\circ} \mathrm{C}$, while the range for 291 the USA was $33.3-37.8^{\circ} \mathrm{C}$, with an average maximum of $35.2^{\circ} \mathrm{C}$. As with sea surface 292 temperatures, the seasonal range in air temperature was much greater for the western Atlantic 293 population: $50.8^{\circ} \mathrm{C}$ in the USA versus $35.6^{\circ} \mathrm{C}$ in the eastern Atlantic. The disparity been 294 tolerance and habitat temperatures could partially reflect the fact that while emerged at low tide, 295 the body temperature of a mussel may be higher than the ambient air temperature (Hofmann and 296 Somero, 1995; Denny et al., 2011, this volume). However, overall, the suggestion that more 297 warm-adapted species tend to live closer to their thermal tolerance limits (Stillman and Somero, 298 2000; Somero, 2005, 2010; Compton et al., 2007; Bonebrake and Mastandrea, 2010) does not 299 appear to be the case for these mussel populations. The population with the highest thermal 300 tolerances (FR) experienced cooler temperatures and a narrower seasonal temperature range 
301 whereas mussels in the population with lower thermal tolerances (USA) inhabited locations with 302 higher maximum habitat temperatures and a broader temperature range.

303 Repeated, chronic exposures to high temperatures have been demonstrated to have 304 negative effects on a variety of organisms, impacting foraging behavior in the marine intertidal 305 seastar Pisaster ochraceus (Pincebourde et al., 2008), growth of the benthic stream minnow 306 Rhinichthys cobitis (Widmer et al., 2006), and fecundity and viability in the fruit fly Drosophila 307 melanogaster (Dillon et al., 2007). A decrease in upper thermal tolerance after repeated 308 exposures has been observed in other mussel species, including Mytilus trossulus, M. 309 galloprovincialis, and M. californianus, from the west coast of the USA (S. Jones and N. 310 Mieszkowska, unpubl. data), in addition to that shown here for M. edulis from the Atlantic. 311 While the physiological mechanisms underlying these results are unknown, we suggest that they 312 could reflect costs associated with sublethal stress, such as the expression of heat-shock proteins. 313 Hilbish et al. (unpubl. data) determined that the threshold induction temperature of the heat314 shock response for $M$. edulis from the USA was between 29 and $32^{\circ} \mathrm{C}$, which is very close to the $315 \mathrm{LT}_{50}$ values derived from the temperature tolerance experiments. Repeated exposures to such 316 high temperatures may override the heat-shock response: Chapple et al. (1998) found that $M$. 317 edulis could not acclimate to temperatures above 28.5C, and Hilbish et al. (unpubl. data) showed 318 that heat-shock protein expression increased with temperatures up to $32^{\circ} \mathrm{C}$ but declined 319 dramatically at $35^{\circ} \mathrm{C}$. These data indicate that the heat-shock response may not be able to 320 compensate for repeated exposures to high temperatures, increasing the probability of mortality 321 with more frequent heat exposure. Many intertidal organisms tend to live at the limits of their temperature tolerances, both 323 within the intertidal zone and on a geographic scale (Connell, 1961, 1972; Wolcott, 1973; 
324 Newell, 1979; Wethey, 2002; Jones et al., 2009), and Mytilus is no exception. Analysis of 325 intertidal temperature records for the east coast of the USA and northern Europe indicated that 326 between two and five consecutive daily exposures to high temperatures typically occur during a 327 spring tidal cycle (S. Jones, unpubl. data; B. Helmuth and N. Mieszkowska, unpubl. data). As a 328 result, high mortality in response to these repeated exposures has been documented (Jones et al., 329 2010). Increases in ambient temperature due to climatic change, and increases in the frequency 330 of heat waves, could therefore affect both small- and large-scale distributions. For M. edulis 331 along the western Atlantic, a range contraction of approximately $350 \mathrm{~km}$ in response to rising 332 temperatures has already been documented (Jones et al., 2010). However, such a change in 333 distribution has not been seen for M. edulis along the eastern Atlantic (Wethey et al., 2011, this 334 volume), which could be due to the fact that temperature tolerances in northern France are much 335 higher than those on the USA east coast.

\section{Within-region variation in northwest Atlantic littorine snails}

Repeated exposure to temperature change in the long term, however, may allow acclimatization, which can protect populations from extreme temperature and mortality episodes.

340 We determined the temperature tolerance of littorine snail congeners along a latitudinal and temperature gradient in the northwest Atlantic to assess within-region variation in tolerance, and two lab-acclimation treatments allowed examination of relative acclimatization and acclimation 343 ability. 
347 northern Maine (Hamilton Cove, near Quoddy Head; $44.7867^{\circ} \mathrm{N}, 67.0064^{\circ} \mathrm{W}$ ), southern Maine 348 (Pemaquid Point; $43.8406^{\circ} \mathrm{N} 69.5098^{\circ} \mathrm{W}$ ), Massachusetts (East Point, Nahant; $42.4195^{\circ} \mathrm{N}$, $34970.9023^{\circ} \mathrm{W}$ ), and Rhode Island (Kings Beach; $41.3856^{\circ} \mathrm{N}, 71.6639^{\circ} \mathrm{W}$; except no L. saxatilis 350 were collected from this site). Individuals were kept in the laboratory with running seawater at $35117^{\circ} \mathrm{C}$ for acclimation periods of either 5 days or 3 weeks with $n=12$ per species $\mathrm{x}$ site $\mathrm{x}$ 352 acclimation time. Snails acclimated for 3 weeks were fed ad libitum with the alga Fucus 353 vesiculosis, replaced twice per week.

354 Temperature tolerance (emersed, at 100\% humidity) was quantified using methods 355 detailed in Sorte and Hofmann (2005), with exceptions as noted. We raised the temperature in 356 experimental vials to $40^{\circ} \mathrm{C}$ at a rate of $1{ }^{\circ} \mathrm{C}$ every $5 \mathrm{~min}$, exposed snails to $40^{\circ} \mathrm{C}$ for $1 \mathrm{~h}$, and 357 returned snails to ambient, running seawater for a 90 min recovery period. Tolerance was scored 358 based on responsiveness to probing according to Bertness and Schneider (1976): $0=$ dead, no 359 response; $1=$ moribund, slight response indicating a compromised ability to reattach to the 360 substrate and, thus, potential mortality via wave displacement; and $2=$ alive, responsive to 361 probing. These values were averaged across replicates to obtain a thermotolerance index ranging 362 from 0.0 (low) to 2.0 (high). Geographic variation in temperature tolerance (log-transformed 363 values) was assessed by ANCOVA using snail size (measured as operculum width) as the 364 covariate. The size* site interaction was not included in the model when slopes were 365 homogeneous. We ran a separate ANCOVA for each species x acclimation group and used least366 squares means for multiple comparisons. We examined residual plots to ensure that the data met 367 requirements of normality and homogeneity of variances, and we present all data as means \pm SE. 
Temperature tolerance varied geographically between field-acclimatized (5-day acclimated) populations of L. obtusata (site $\left.F_{3,44}=9.08, p<0.0001\right)$ and $L$. saxatilis $\left(\right.$ site $F_{2,32}=$ 4.66, $p=0.017$ ). For the low to mid-intertidal littorines, L. littorea and L. obtusata, temperature tolerance of field-acclimatized individuals was highest in the Rhode Island population (i.e. the warmest site) and lowest in the Maine populations (Fig. 5). L. littorea tolerances tended to increase monotonically with decreasing latitude (site $p=0.103$ ) whereas L. obtusata tolerances were lowest in the southern Maine population $(p<0.0001)$. Interestingly, for the high intertidal species L. saxatilis, tolerance was highest at the northern Maine location $(p=0.017)$, although, since this species was not collected at the warmest Rhode Island site, our latitudinal comparison was more limited. Thus, these Littorina species tend to have less tolerant phenotypes north of Cape Cod, a biogeographic barrier between different thermal habitats (Engle and Summers, 1999; Fig. 5A). At the same time, our comparisons indicate that differences between sites separated by $<200 \mathrm{~km}$ (e.g. L. obtusata in southern versus northern Maine) can be as significant as, or greater than, those between sites with >500 km geographic separation. Similarly, Davenport and Davenport (2005) showed that within a suite of 10 rocky intertidal species, differences in thermal niche widths were often the same or greater between sites within a single region than between multiple regions (but see Fangue et al., 2006 for an example of a species with tolerance variation only between, but not within, regions).

Temperature tolerances tended to increase after 3 weeks of laboratory acclimation for all 11 populations examined (Fig. 5A). However, the effect of the acclimation period on the degree of geographic variation in temperature tolerance between populations differed by species. For $L$. obtusata and L. saxatilis, the significant geographic variation in tolerance disappeared $(L$. obtusata: site $p>0.2$ ) or was obscured (L. saxatilis: site $p=0.062$ ) after the acclimation period. 
392 Conversely, for L. littorea, the geographic variation became more pronounced after acclimation 393 (site $F_{3,40}=4.09, p=0.0127$ ), with the acclimation capacity of the northern Maine snails lagging 394 behind that of the more southern populations. Among these 11 populations of littorine snails, 395 only two populations - L. littorea from northern Maine and L. saxatilis from southern Maine 396 were unable to 'keep up with' their southern counterparts that were more tolerant and better able 397 to acclimate (Fig. 5). Of these species, L. littorea, which releases eggs that hatch into pelagic 398 larvae, has a greater ability for more tolerant populations to recolonize and 'rescue' less tolerant 399 populations than the other two direct-developing species that have shorter dispersal distances 400 (Reid, 1996).

Among these three littorines, L. obtusata, while able to acclimate to increased 402 temperature, had tolerance levels that were still well below those of the other species. Average 403 tolerance scores for L. obtusata were $1.2 \pm 0.2$ for both Maine populations after the acclimation 404 period, or slightly higher than 'moribund' (score of 1) which Bertness and Schneider (1976) 405 suggested is approximately the point of 50\% mortality. Even if some populations manage to 406 acclimatize sufficiently to avoid high mortality (e.g. the Rhode Island population achieved a 407 tolerance score of $1.6 \pm 0.2$ after the 3 week acclimation), dispersal distance is low due to this 408 species' life-history strategy. However, L. obtusata are also often found amongst the blades of 409 their fucoid algal food source (C. Sorte, unpubl. data) which could provide a temperature refuge. 410 Thus, for littorines as well as other marine species, microhabitat buffering (i.e. movement into 411 nearby algal canopies, rock crevices, and cracks) and other behavioral responses (e.g., Williams 412 et al., 2005; Miller, 2008) could ameliorate stressful exposures (Williams et al., 2008). Overall, 413 this case study illustrates the need to consider acclimatization capacity when attempting to 
414 project population- and species-level responses to climate change, and future studies exploring

415 the role of dispersal ability and behavioral responses are warranted.

417 5. Overview

The geographic distribution of a species tends to be closely linked with climate, and understanding that relationship is imperative when predicting impacts of climatic change. Hutchins (1947) argued that geographic limits are set by thermal tolerances, and in many cases

421 correspondences have been demonstrated between geographic and physiological limits (e.g.

422 Vernberg and Vernberg, 1967; Sorte and Hofmann, 2005; Jones et al., 2009; Somero, 2010).

423 Marine ectotherms, such as tunicates, bryozoans, bivalves, and gastropods, may be particularly 424 sensitive indicators of climate change (Somero, 2002; Mieszkowska et al., 2005; Helmuth et al., 425 2006). While studies of species-specific temperature tolerance are relatively common, fewer data 426 are available regarding how tolerances vary on a geographic scale between populations within a 427 single species (O’Neill et al., 2008; Kuo and Sanford, 2009; but see e.g. Urban, 1994; Zippay 428 and Hofmann, 2010).

We examined the variation in thermal tolerances between widely geographically

430 separated populations within species of tunicates (Diplosoma listerianum, Botrylloides violaceus, and Botryllus schlosseri), bryozoans (Bugula neritina), and bivalves (Mytilus edulis). Contrary to

432 some previous findings (e.g. Goto and Kimura, 1998; Gaston and Chown, 1999; Addo-Bediako 433 et al., 2000; Kimura, 2004), our results indicate that upper thermal thresholds do vary between 434 geographically separated populations. Among the subtidal tunicates and bryozoans, differences 435 in $\mathrm{LT}_{50}$ values ranged from 1.1 to $2.1^{\circ} \mathrm{C}$ between the west and east coast USA populations, and, 436 in each case, tolerance was significantly greater for populations on the east coast. Upper thermal 
437 tolerances also varied between two widely separated populations of the intertidal mussel $M$.

438 edulis. After five daily consecutive exposures, thermal tolerance was greater in the population

439 from the eastern Atlantic (FR) than in the western Atlantic (USA) population, with differences of $440 \quad 4.5$ and $2.5^{\circ} \mathrm{C}$ in air and water, respectively.

For the tunicates and bryozoans, the differences in thermal tolerances paralleled

442 differences in habitat temperatures. The populations examined along the east coast of the USA

443 had both higher tolerances and habitat temperatures than populations along the west coast;

444 however, east coast populations are also currently living closer to their upper tolerance limits and 445 facing greater projected temperature increases. In contrast, differences between thermal 446 tolerances of the two mussel populations did not correspond directly with those in habitat 447 temperatures. Mussels from the western Atlantic had lower thermotolerance thresholds but 448 experienced higher habitat temperatures and are residing closer to their tolerance limits. 449 Meanwhile, mussels from the eastern Atlantic had higher thermotolerance thresholds but 450 experienced a narrower range of habitat temperatures and may, therefore, be less vulnerable to 451 temperature increases. It is important to note, however, that these relative climate susceptibilities 452 could be reversed if, as shown for other marine species, the more thermotolerant populations 453 have lower acclimation abilities (Stillman, 2003; Somero, 2010). While the direction of the current relationship between habitat temperature and 455 temperature tolerance differs between the subtidal epibenthic and intertidal mussel species 456 examples, in both cases, the populations residing along the east coast of the USA (western 457 Atlantic) appear to be most vulnerable to the projected increases in local temperatures. The 458 highly seasonal USA east coast is characterized by a more 'continental' climate in relation to the 459 more temperate 'maritime' climates of the USA west coast and western Europe due to 
460 differences in wind and current patterns in these regions (Seager et al., 2002). Thus, our results

461 seem to corroborate a general difference in projected impacts between regions with 'continental'

462 versus 'maritime' climates (e.g. Smith et al., 1999; Hamann and Wang, 2006), similar to the

463 already well-appreciated differences in climate-change susceptibility across latitudes (e.g. Addo-

464 Bediako et al., 2000; Deutsch et al., 2008; Bonebrake and Mastandrea, 2010).

465 Temperature tolerances vary on both large and small spatial scales. Within the intertidal

466 zone, average habitat temperature corresponds with tidal height, and Sokolova et al. (2000)

467 demonstrated that temperature tolerances may be more highly variable across different tidal

468 heights within a site than between regions. Within-region variation was demonstrated for

469 gastropod congeners (Littorina sp.) from the northwest Atlantic, and, in most populations,

470 tolerances paralleled habitat temperatures: organisms at warmer sites tended to have higher

471 tolerances. In addition, individuals from the highest latitude population examined (in northern

472 Maine) had reduced acclimation capacities. Since high latitude locations are warming most

473 rapidly with changing climate (Trenberth et al., 2007), northern populations may be at a greater

474 disadvantage with continued warming.

475 Because geographic variation in temperature tolerance within a species could be due to

476 acclimation and/or adaptation (Kuo and Sanford, 2009), differences in life-history strategies will

477 likely play an important role in the response of populations to increasing temperatures (Somero,

478 2010). Organisms with reduced dispersal distances, limited acclimatization ability, and low

479 thermal tolerances are considered to be at the greatest risk under a regime of climate warming

480 (Harley et al., 2006; Deutsch et al., 2008; Somero, 2010). Conversely, organisms with pelagic

481 larval dispersal, and therefore extensive gene flow and little genetic differentiation (Addison et

482 al., 2008), are expected to have limited potential for local adaptation (Conover et al., 2006), and 
483 pelagic dispersal is only an advantage if gene flow is from more tolerant populations and towards 484 less tolerant populations. Among the gastropod species examined, one has a pelagic larval stage 485 (L. littorea), and this possibility for the 'rescue' of less tolerant, vulnerable populations exists if 486 larvae are able to disperse from a southern, warm-adapted population with individuals of high 487 acclimation potential to a more northern, cold-adapted population. Conversely, in the cases of $L$. 488 obtusata and L. saxatilis that have direct-developing, crawl-away larvae, exchange between 489 populations decreases dramatically with increasing distance. Thus, the possibility of 'rescue' or 490 recolonization is much less; at the same time, there may be advantages for populations of 491 increased potential for local adaptation to current conditions (Kuo and Sanford, 2009). Sensitivity to climate change is determined by intrinsic factors such as physiological 493 limits, ecological traits, and genetic diversity (Williams et al., 2008). Our case studies examined 494 geographic variation in temperature tolerance spanning a range of spatial scales and organisms, 495 and these studies highlight several populations living closest to their upper thermal limits. In 496 comparison to populations along the eastern Pacific or eastern Atlantic, the populations residing 497 in the more 'continental' climate of the western Atlantic, including tunicates, bryozoans, and 498 mussels, are those living nearest their temperature tolerance thresholds. By 2099, predicted 499 increases in temperature have the potential to seriously impact these populations, and past 500 temperature increases since 1960 have already caused increases in mortality events and range 501 contractions (Jones et al., 2010). In addition, sublethal physiological stress tends to reduce fitness 502 (Menge and Sutherland, 1987), and chronic stress caused a reduction in the upper thermal 503 tolerances of the mussel populations considered here. Thus, the increase in frequency of extreme 504 temperatures that is predicted (see Meehl and Tebaldi, 2004) may have severe, short-term 505 consequences for populations. Mitigation of the adverse effects of climate change will be 
506 determined by processes such as acclimatization, adaptation, and dispersal (Deutsch et al., 2008), 507 and future studies should continue to examine whether these mechanisms are able to compensate 508 for temperature increases.

509

510 Acknowledgments

511 We especially thank R. Wong and R. Zerebecki for running many of the tolerance

512 experiments and M. Bracken for statistical assistance and helpful comments. We thank K. Benes, 513 N. Low, B. Taggart, D. Wethey, and S. Woodin for additional assistance and feedback. Funding 514 was provided by a College of Biological Sciences Dean's Circle Mentorship Award from UC515 Davis to CJBS and grants from NSF (OCE1039513), NOAA (NA04NOS4780264), and NASA 516 (NNG04GE43G and NNX07AF20G). This publication is contribution number 273 of the Marine 517 Science Center of Northeastern University.

\section{References}

520 Addison, J.A., Ort, B.S., Mesa, K.A., Pogson, G.H., 2008. Range-wide genetic homogeneity in 521 the California sea mussel (Mytilus californianus): a comparison of allozymes, nuclear DNA markers, and mitochondrial DNA sequences. Mol. Ecol. 17, 4222-4232.

523 Addo-Bediako, A., Chown, S.L., Gaston, K.J., 2000. Thermal tolerance, climatic variability, and latitude. Proc. Roy. Soc. Lond. B. 267, 739-745.

525 Bertness, M.D., Schneider, D.E., 1976. Temperature relations of Puget Sound Thaids in 526 reference to their intertidal distribution. Veliger. 19, 47-58. 
527 Bonebrake, T.C., Mastrandrea, M.D., 2010. Tolerance adaptation and precipitation changes

528

529

530

531

532

533

534

535

536

537

538

539

540

541

542

543

544

545

546

547

548 complicate latitudinal patterns of climate change impacts. Proc. Natl. Acad. Sci. USA. $107,12581-12586$.

Calosi, P., Bilton, D.T., Spicer, J.I., 2008. Thermal tolerance, acclimatory capacity and vulnerability to global climate change. Biol. Lett. 4, 99-102.

Chapple, J.P., Smerdon, G.R., Berry, R.J., Hawkins, A.J.S., 1998. Seasonal changes in stress-70 protein levels reflect thermal tolerance in the marine bivalve Mytilus edulis L. J. Exp. Mar. Biol. Ecol. 229, 53-68.

Cohen, A.N., 2005. Guide to the exotic species of San Francisco Bay. San Francisco Estuary Institute, Oakland, California (http://www.exoticsguide.org).

Compton, T.J., Rijkenberg, M.J.A., Drent, J., Piersma, T., 2007. Thermal tolerance ranges and climate variability: a comparison between bivalves from differing climates. J. Exp. Mar. Biol. Ecol. 352, 200-211.

Connell, J.H., 1961. The influences of interspecific competition and other factors on the distribution of the barnacle Chthamalus stellatus. Ecology. 42, 710-723.

Connell, J.H., 1972. Community interactions on marine rocky intertidal shores. Annu. Rev. Ecol. Syst. 3, 169-192.

Conover, D.O., Clarke, L.M., Munch, S.B., Wagner, G.N., 2006. Spatial and temporal scales of adaptive divergence in marine fishes and the implications for conservation. J. Fish Biol. 69, 21-47.

Davenport, J., Davenport, J.L., 2005. Effects of shore height, wave exposure and geographical distance on thermal niche width of intertidal fauna. Mar. Ecol. Prog. Ser. 292, 41-50. 
Denny, M.W., Dowd, W.W., Bilir, L., Mach, K.J., 2011. Spreading the risk: Small-scale body temperature variation among intertidal organisms and its implications for species persistence. J. Exp. Mar. Biol. Ecol. This issue.

Deutsch, C.A., Tewksbury, J.J., Huey, R.B., Sheldon, K.S., Ghalambor, C.K., Haak, D.C., Martin, P.R., 2008. Impacts of climate warming on terrestrial ectotherms across latitude. Proc. Natl. Acad. Sci. USA. 105, 6668-6672.

Dillon, M.E., Cahn, L.R.Y., Huey, R.B., 2007. Life history consequences of temperature transients in Drosophila melanogaster. J. Exp. Biol. 210, 2897-2904.

Engle V.D., Summers J.K., 1999. Latitudinal gradients in benthic community composition in Western Atlantic estuaries. J. Biogeogr. 26, 1007-1023.

Fangue, N.A., Hofmeister, M., Schulte, P.M., 2006. Intraspecific variation in thermal tolerance and heat shock protein gene expression in common killifish, Fundulus heteroclitus. J. Exp. Biol. 209, 2859-2872.

Firth, L.B., Williams, G.A., 2009. The influence of multiple environmental stressors on the limpet Cellana toreuma during the summer monsoon season in Hong Kong. J. Exp. Mar. Biol. Ecol. 375, 70-75.

Fitzhenry, T., Halpin, P.M., Helmuth, B., 2004. Testing the effects of wave exposure, site, and behavior on intertidal mussel body temperatures: applications and limits of temperature logger design. Mar. Biol. 145, 339-349.

Garrabou, J., Coma, R., Bensoussan, N., Bally, M., Chevaldonne, P., Cigliano, M., Diaz, D., Harmelin, J.G., Gambi, M.C., Kersting, D.K., 2009. Mass mortality in Northwestern Mediterranean rocky benthic communities: effects of the 2003 heat wave. Glob. Change Biol. 15, 1090-1103. 
572 Gaston, K.J., Chown, S.L., 1999. Elevation and climatic tolerance: a test using dung beetles. $573 \quad$ Oikos. 584-590.

574 Ghalambor, C.K., Huey, R.B., Martin, P.R., Tewksbury, J.J., Wang, G., 2006. Are mountain 575 passes higher in the tropics? Janzen's hypothesis revisited. Integ. Comp. Biol. 46, 5-17.

576 Gilman, S.E., Wethey, D.S., Helmuth, B., 2006. Variation in the sensitivity of organismal body 577 temperature to climate change over local and geographic scales. Proc. Natl. Acad. Sci. $578 \quad$ USA. $103,9560-9565$.

579 Goto, S.G., Kimura, M.T., 1998. Heat- and cold-shock responses and temperature adaptations in 580 subtropical and temperate species of Drosophila. J. Insect Physiol. 44, 1233-1239.

581 Grosholz, E.D., 2001. Small spatial-scale differentiation among populations of an introduced 582 colonial invertebrate. Oecologia. 129, 58-64.

583 584 585 586 587 588 589 590 591 592 593
Hamann, A., Wang, T., 2006. Potential effects of climate change on ecosystem and tree species distribution in British Columbia. Ecology. 87, 2773-2786.

Harley, C.D.G., Hughes, A.R., Hultgren, K.M., Miner, B.G., Sorte, C.J.B., Thornber, C.S., Rodriguez, L.F., Tomanek, L., Williams, S.L., 2006. The impacts of climate change in coastal marine systems. Ecol. Lett. 9, 228-241.

Helmuth, B., Mieszkowska, N., Moore, P., Hawkins, S.J., 2006. Living on the edge of two changing worlds: forecasting the responses of rocky intertidal ecosystems to climate change. Ann. Rev. Ecol. Evol. Syst. 37, 373-404.

Herbert, R.J.H., Hawkins, S.J., Sheader, M., Southward, A.J., 2003. Range extension and reproduction of the barnacle Balanus perforatus in the eastern English Channel. J. Mar. Biol. Assoc. UK 83, 73-82. 
594 Hofmann, G.E., Somero G.N., 1995. Evidence for protein damage at environmental

595

596

597

598

599

600

601

602

603

604

605

606

607

608

609

610

611

612

613

614

615

616 temperatures: seasonal changes in levels of ubiquitin conjugates and hsp70 in the intertidal mussel Mytilus trossulus. J. Exp. Biol. 198, 1509-1518.

Hutchins, L.W., 1947. The bases for temperature zonation in geographical distribution. Ecol. Monogr. 17, 325-335.

Intergovernmental Panel on Climate Change Working Group III, 2000. Summary for policymakers: emissions scenarios. GRID-Arendal, Norway.

Janzen, D.H., 1967. Why mountain passes are higher in the tropics. Am. Nat. 101, 233-249.

Jones, S.J., Mieszkowska, N., Wethey, D.S., 2009. Linking thermal tolerances and biogeography: Mytilus edulis (L.) at its southern limit on the east coast of the United States. Biol. Bull. 217, 73-85.

Jones, S.J., Lima, F.P., Wethey, D.S., 2010. Rising environmental temperatures and biogeography: poleward range contraction of the blue mussel, Mytilus edulis L., in the western Atlantic. J. Biogeogr. 37, 2243-2259.

Kimura, M.T., 2004. Cold and heat tolerance of drosophilid flies with reference to their latitudinal distributions. Oecologia. 140, 442-449.

Kuo, E.S.L., Sanford, E., 2009. Geographic variation in the upper thermal limits of an intertidal snail: implications for climate envelope models. Mar. Ecol. Prog. Ser. 388, 137-146.

Lockwood, B.L., Somero, G.N., 2011. Invasive and native blue mussels (genus Mytilus) on the California coast: the role of physiology in a biological invasion. J. Exp. Mar. Biol. Ecol. This issue.

Marbà, N., Duarte, C.M., 2010. Mediterranean warming triggers seagrass (Posidonia oceanica) shoot mortality. Glob. Change Biol. 16, 2366-2375. 
617 Meehl, G.A., Tebaldi, C., 2004. More intense, more frequent and longer lasting heat waves in the $618 \quad 21$ st century. Science. 305, 994-997.

619 Meehl, G.A., Covey, C., Delworth, T.L., Latif, M., Mcavaney, B., Mitchell, J.F.B., Stouffer, 620 R.J., Taylor, K.E., 2007. The WCRP CMIP3 multimodel dataset. Bull. Am. Meteorol. 621 Soc. $88,1383-1394$.

622 Menge, B.A., Sutherland, J.P., 1987. Community regulation: variation in disturbance, 623 624 625 626 627 competition, and predation in relation to environmental stress and recruitment. Am. Nat. $130,730-757$.

Mieszkowska, N., Leaper, R.,Moore, P., Kendall, M.A., Burrows, M.T., Lear, D., Poloczanska, E., Hiscock, K., Moschella, P.S., Thompson, R.C., Herbert, R.J., Laffoley, D., Baxter, J., Southward, A.J., Hawkins, S.J., 2005. Marine biodiversity and climate change: assessing and predicting the influence of climatic change using intertidal rocky shore biota. Final report for United Kingdom funders. Mar. Biol. Assoc. Occas. Publ. 20, 1-53.

Miller, L.P. 2008. Life on the edge: morphological and behavioral adaptations for survival on wave-swept shores. Ph.D. Thesis, Stanford University. 205 pp.

632 Miller, L.P., Harley, C.D.G., Denny, M.W., 2009. The role of temperature and desiccation stress 633 in limiting the local-scale distribution of the owl limpet, Lottia gigantea. Funct. Ecol. 23, $634 \quad 756-767$.

635 Newell, R.C. 1969. Effect of fluctuations in temperature on the metabolism of intertidal 636 invertebrates. Amer. Zool. 9, 293-307.

637 Newell, R.C. 1979. Biology of intertidal animals. Marine Ecological Surveys Ltd., Faversham, $638781 \mathrm{pp}$. 
639 O’Neill, G.A., Hamann, A., Wang, T., 2008. Accounting for population variation improves 640 estimates of the impact of climate change on species' growth and distribution. J. Appl. Ecol. 45, 1040-1049.

642

643

644 645

646

647

648 649

650

651

652

653

654

655

656

657

658

659

660

Pearce, J.B., 1969. Thermal addition and the benthos, Cape Cod Canal. Chesapeake Sci. 10, $227-$ 233.

Pincebourde, S., Sanford, E., Helmuth, B., 2008. Body temperature during low tide alters the feeding performance of a top intertidal predator. Limnol. Oceanogr. 53, 1562-1573.

Poloczanska, E.S., Smith, S., Faunonneta, L., Healy, J., Tibbetts, I.R., Burrows, M.T., Richardson, A.J., 2011. Little change in the distribution of rocky shore faunal communities on the Australian east coast after 50 years of rapid warming. J. Exp. Mar. Biol. Ecol. This issue.

R Core Development Team, 2010. R: A language and environment for statistical computing. R Foundation for Statistical Computing, Vienna, Austria.

Rajagopal, S., Van Der Velde, G., Van Der Gaag, M., Jenner, H.A., 2005. Factors influencing the upper temperature tolerances of three mussel species in a brackish water canal: size, season, and laboratory protocols. Biofouling. 21, 87-97.

Read, K.R.H., Cumming, K.B., 1967. Thermal tolerance of the bivalve mollusks Modiolus modiolus (L.), Mytilus edulis (L.) and Brachidontes demissus Dillwyn. J. Comp. Biochem. Physiol. 22, 149-155.

Reid, D.G., 1996. Systematics and evolution of Littorina. Dorset Press, Dorchester, Dorset, UK. Reynolds, R.W., Smith, T.M., Liu, C., Chelton, D.B., Casey, K.S., Schlax, M.G., 2007. Daily high-resolution-blended analyses for sea surface temperature. J. Clim. 20, 5473-5496. 
661 Ritchie, J., 1927. Report on the prevention of the growth of mussels in submarine shafts and 662 tunnels at Westbank Electricity Station, Portobello. Trans. Roy. Scot. Soc. Arts. 19, 1-20.

663 Seager, R., Battisti, D.S., Yin, J., Gordon, N., Naik, N., Clement, A.C., Cane, M.A., 2002. Is the 664 Gulf Stream responsible for Europe's mild winters? Q. J. R. Meteorol. Soc. 127, 2563-

665 2586.

666

667

668

669

670

671

672

673

674

675

676

677

678

679

680

681

682

Smith, R.C., Ainley, D., Baker, K., Domack, E., Emslie, S., Fraser, B., Kennett, J., Leventer, A., Mosley-Thompson, E., Stammerjohn, S., Vernet, M., 1999. Marine ecosystem sensitivity to climate change. BioScience. 49, 393-404.

Sokolova, I.M., Granovitch, A.I., Berger, V.J., Johannesson, K., 2000. Intraspecific physiology variability of the gastropod Littorina saxatilis related to the vertical shore gradient in the White and North Seas. Mar. Biol. 137, 297-308.

Somero, G.N., 2002. Thermal physiology and vertical zonation of intertidal animals: optima, limits, and costs of living. Integ. Comp. Biol. 42, 780-789.

Somero, G.N., 2005. Linking biogeography to physiology: Evolutionary and acclamatory adjustments of thermal limits. Front. Zool. 2, 1-9.

Somero, G.N., 2010. The physiology of climate change: how potentials for acclimatization and genetic adaptation will determine the 'winners' and 'losers'. J. Exp. Biol. 213, 912-920.

Sorte, C.J.B., Hofmann, G.E., 2005. Thermotolerance and heat-shock protein expression in Northeastern Pacific Nucella species with different biogeographical ranges. Mar. Biol., 146, 985-993.

Sorte, C.J.B., Stachowicz, J.J., in review. Patterns and processes of compositional change in a California epibenthic community. Mar. Ecol. Prog. Ser. 
683 Sorte, C.J.B., Williams, S.L., Carlton, J.T., 2010a. Marine range shifts and species introductions: 684 comparative spread rates and community impacts. Glob. Ecol. Biogeogr. 19, 303-316.

685 Sorte, C.J.B., Williams, S.L., Zerebecki, R.A., 2010b. Ocean warming increases threat of 686 invasive species in a marine community. Ecology. 91, 2198-2204.

687 Sorte, C.J.B., Fuller, A., Bracken, M.E.S., 2010c. Impacts of a simulated heat wave on 688 composition of a marine community. Oikos. 119, 1909-1918.

689

690

Southward, A.J., Hawkins, S.J., Burrows, M.T., 1995. Seventy years' observations of changes in 691 distribution and abundance of zooplankton and intertidal organisms in the western English Channel in relation to rising sea temperature. J. Therm. Biol. 20, 127-155.

Stenseng, E., Braby, C.E., Somero, G.N., 2005. Evolutionary and acclimation-induced variation 693 in the thermal limits of heart function in congeneric marine snails (Genus Tegula): implications for vertical zonation. Biol. Bull. 208, 138-144.

Stillman, J.H., 2002. Causes and consequences of thermal tolerance limits in rocky intertidal 696 porcelain crabs, genus Petrolisthes. Integ. Comp. Biol. 42, 790-796.

697 Stillman, J.H., 2003. Acclimation capacity underlies susceptibility to climate change. Science. 301, 65.

Stillman, J.H., Somero, G.N., 2000. A comparative analysis of the upper thermal tolerance limits 700 of eastern Pacific porcelain crabs, genus Petrolisthes: influences of latitude, vertical

Tomanek, L., Somero, G.N., 1999. Evolutionary and acclimation-induced variation in the heatshock responses of congeneric marine snails (genus Tegula) from different thermal habitats: implications for limits of thermotolerance and biogeography. J. Exp. Biol. 202, 2925-2936. 
706 Trenberth, K.E., Jones, P.D., Ambenje, P., Bojariu, R., Easterling, D., Klein Tank, A., Parker,

707 708 709
D., Rahimzadeh, F., Renwick, J.A., Rusticucci, M., Soden, B., Zhai, P., 2007.

Observations: surface and atmospheric climate change. Climate change 2007: the physical science basis. In: Solomon, S., Qin, D., Manning, M., Chen, Z. , Marquis, M., Averyt, K.B., Tignor, M., Miller, H.L. (Eds.), Contribution of Working Group I to the Fourth Assessment Report of the Intergovernmental Panel on Climate Change. Cambridge University Press, Cambridge, pp. 235-236.

Urban, H.J., 1994. Upper temperature tolerance of ten bivalve species off Peru and Chile related to El Niño. Mar. Ecol. Prog. Ser. 107, 139-145.

Vellend, M., Harmon, L.J., Lockwood, J.L., Mayfield, M.M., Hughes, A.R., Wares, J.P., Sax, D.F., 2007. Effects of exotic species on evolutionary diversification. Trends Ecol. Evol. $22,481-488$.

Vernberg, F.J., Vernberg, W.B., 1967. Thermal limits of southern hemisphere Uca crabs. Oikos. $18,118-123$.

Wethey, D.S., 2002. Biogeography, competition, and microclimate: the barnacle Chthamalus fragilis in New England. Integ. Comp. Biol. 42, 872-880.

Wethey, D.S., Woodin, S.A., 2008. Ecological hindcasting of biogeographic responses to climate change in the European intertidal zone. Hydrobiologia. 606, 139-151.

Wethey, D.S., Woodin, S.A., Hilbish, T.J., Jones, S.J., Lima, F.P., Brannock, P.M., 2011. Response of intertidal populations to climate: effects of extreme events versus long term change. J. Exp. Mar. Biol. Ecol. This volume. 
727 Widmer, A.M., Carveth, C.J., Bonar, S.A., Simms, J.R., 2006. Upper temperature tolerance of

728

729

730

731

732

733

734

735

736

737

738

739

740

741

742

743 744 loach minnow under acute, chronic, and fluctuating thermal regimes. Trans. Am. Fish. Soc. $135,755-762$.

Williams, G.A., De Pirro, M., Leung, K.M.Y., Morritt, D., 2005. Physiological responses to heat stress on a tropical shore: the benefits of mushrooming behaviour in the limpet Cellana grata. Mar. Ecol. Progr. Ser. 292, 213-224.

Williams, S.E., Shoo, L.P., Isaac, J.L., Hoffmann, A.A., Langham, G., 2008. Towards an integrated framework for assessing the vulnerability of species to climate change. PLoS Biol. 6, 2621-2626.

Wolcott, T.G., 1973. Physiological ecology and intertidal zonation in limpets (Acmaea): a critical look at "limiting factors". Biol. Bull. 145, 389-422.

Yund, P.O., Stires, A., 2002. Spatial variation in population dynamics in a colonial ascidian (Botryllus schlosseri). Mar. Biol. 141, 955-963.

Zerebecki, R.A., Sorte, C.J.B., in review. Temperature tolerance and stress proteins as mechanisms of invasive species success. PLoS ONE.

Zippay, M.L., Hofmann, G.E., 2010. Physiological tolerances across latitudes: thermal sensitivity of larval marine snails (Nucella spp.). Mar. Biol. 157, 707-714. 
$745 \quad$ Figure Legends

746

747 Figure 1. Conceptual diagram of three methods that could allow population persistence in future 748 climate conditions. (A) If future conditions are within the local population's current tolerance 749 range, then survival will continue to be high. (B) If future conditions are within the range of 750 acclimation capacity for this local population, then survival might be low before acclimation but 751 high after acclimation. (C) If tolerance varies between populations connected via dispersal, then 752 individuals from more tolerant source populations could recolonize areas of high mortality (i.e. 753 with less tolerant local populations).

754

755 Figure 2. Temperature-dependent mortality predicted by Probit analysis for (A) the bryozoan 756 Bugula neritina, and the tunicates (B) Botrylloides violaceus, (C) Diplosoma listerianum, and 757 (D) Botryllus schlosseri from the USA west coast (California) and east coast (Massachusetts). 758 For all four species, $\mathrm{LT}_{50}$ was higher on the east coast than on the west coast. Values are based 759 on mortality following a $24 \mathrm{~h}$ exposure to four experimental temperatures (approx. 21, 25, 29, 760 and $\left.34^{\circ} \mathrm{C}\right)$. Replication was as follows: $B$. violaceus and $B$. schlosseri: $n=5$ per temperature; $B$. 761 neritina: $n=7,8,1,4$, respectively; and D. listerianum: $n=3,2,9,6$, respectively.

762

763 Figure 3. Water temperatures from Boston Harbor, Massachusetts (on the USA east coast; black 764 line) and Bodega Harbor, California (on the USA west coast; gray line) for 2005-10. 
766 Figure 4. Calculated $\mathrm{LT}_{50}$ values $( \pm 1 \mathrm{SE})$ for Mytilus edulis after five consecutive exposure 767 events in (A) air and (B) water. Mussels were collected from Normandy, France (dotted line, 768 closed circles) and Massachusetts, USA (solid line, open circles).

769

770 Figure 5. Collection locations (A) and thermal tolerances (B-D) of intertidal Littorina snails 771 from the northwestern Atlantic, USA, including (B) L. obtusata, (C) L. littorea, and (D) $L$. 772 saxatilis. Mean sea surface temperatures (A) across the sampling locations were derived from 773 MODIS-Aqua satellite data for 1-July through 31-August (2002-10). Individual snails $(n=12)$ 774 were collected at Quoddy Head, Maine (ME-N); Pemaquid Point, Maine (ME-S); Nahant, 775 Massachusetts (MA); and Kings Beach, Rhode Island (RI). Snails were lab acclimated for 5 days 776 and 3 weeks to assess field tolerance and acclimation ability, respectively. Thermotolerance was 777 scored (see 'Methods') after a 24 hour emersed exposure to $40^{\circ} \mathrm{C}$ using the following indices: 0 $778=$ dead, $1=$ moribund, and $2=$ alive. Different letters indicate significant geographic variation in 779 tolerance within each species $\mathrm{x}$ acclimation group $(\mathrm{ND}=$ no data). Values are means $\pm 1 \mathrm{SE}$. 
$782 \quad$ Figure 1.

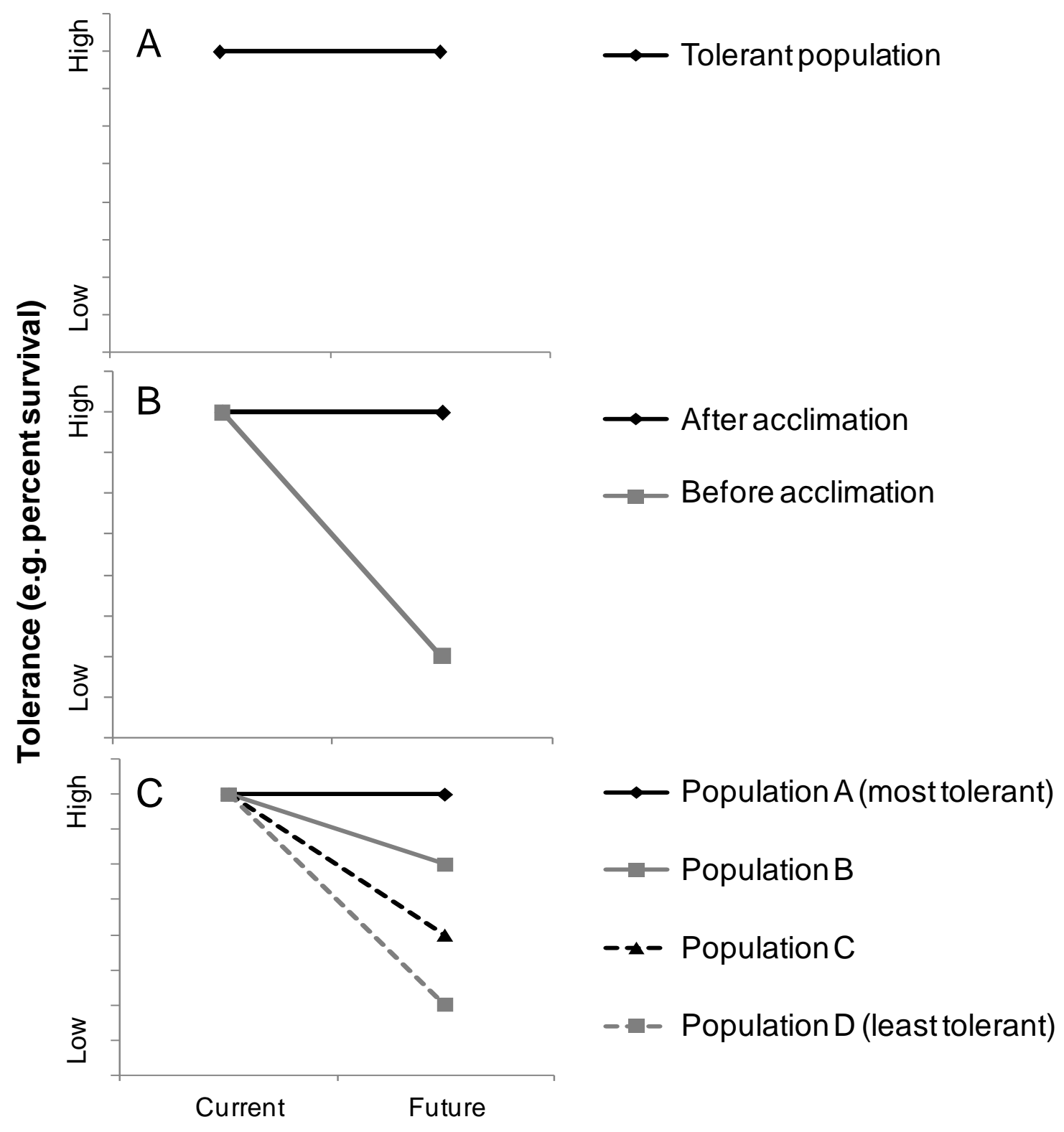


785 Figure 2.

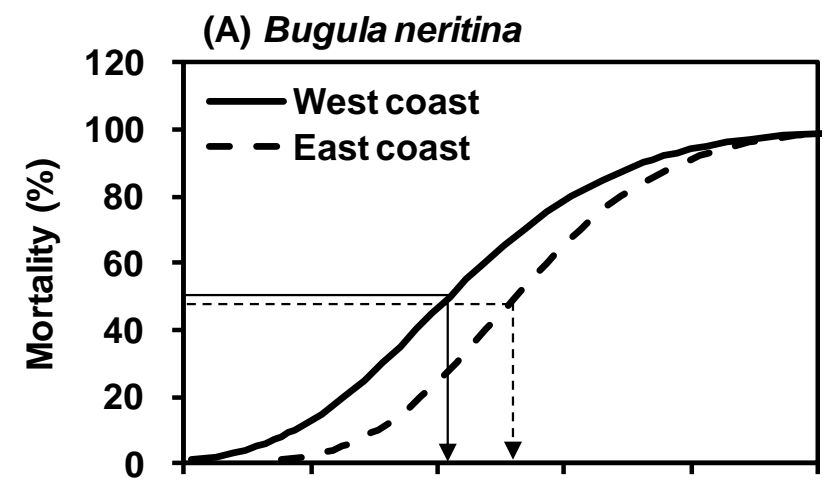

(B) Botrylloides violaceus

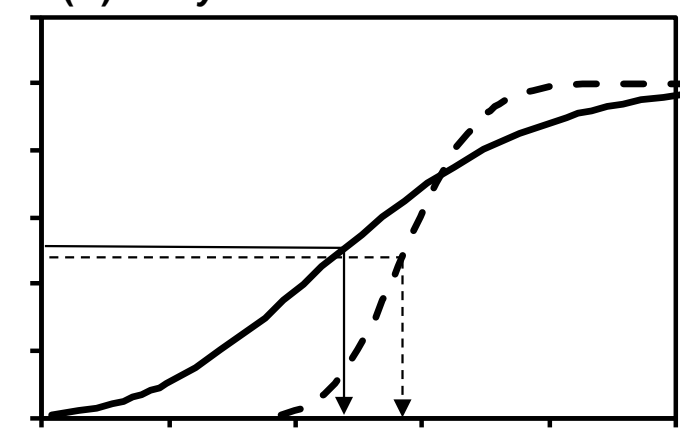

(C) Diplosoma listerianum

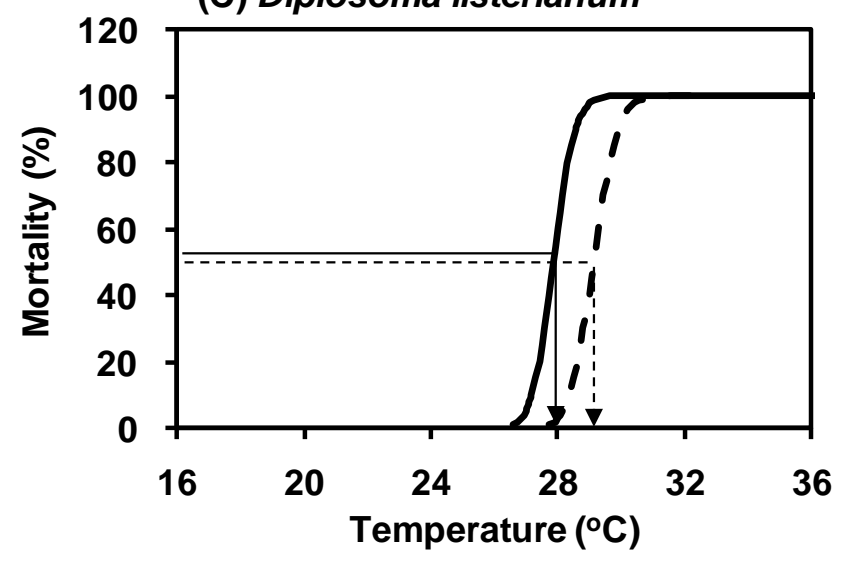

(D) Botryllus schlosseri

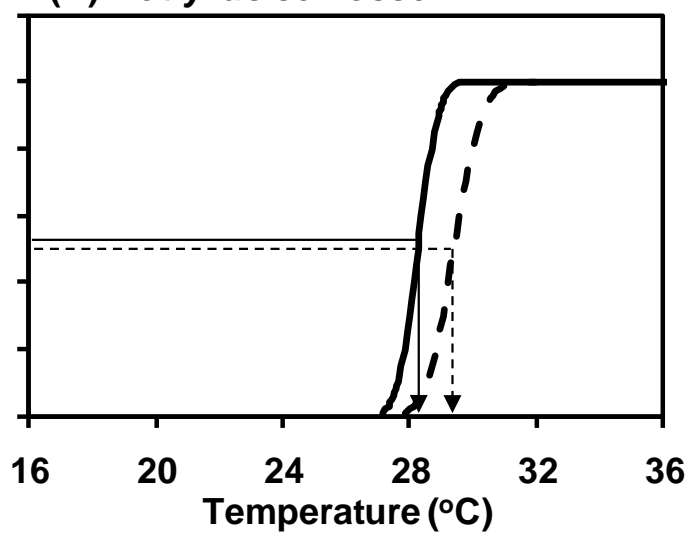

787

788 
Figure 3.

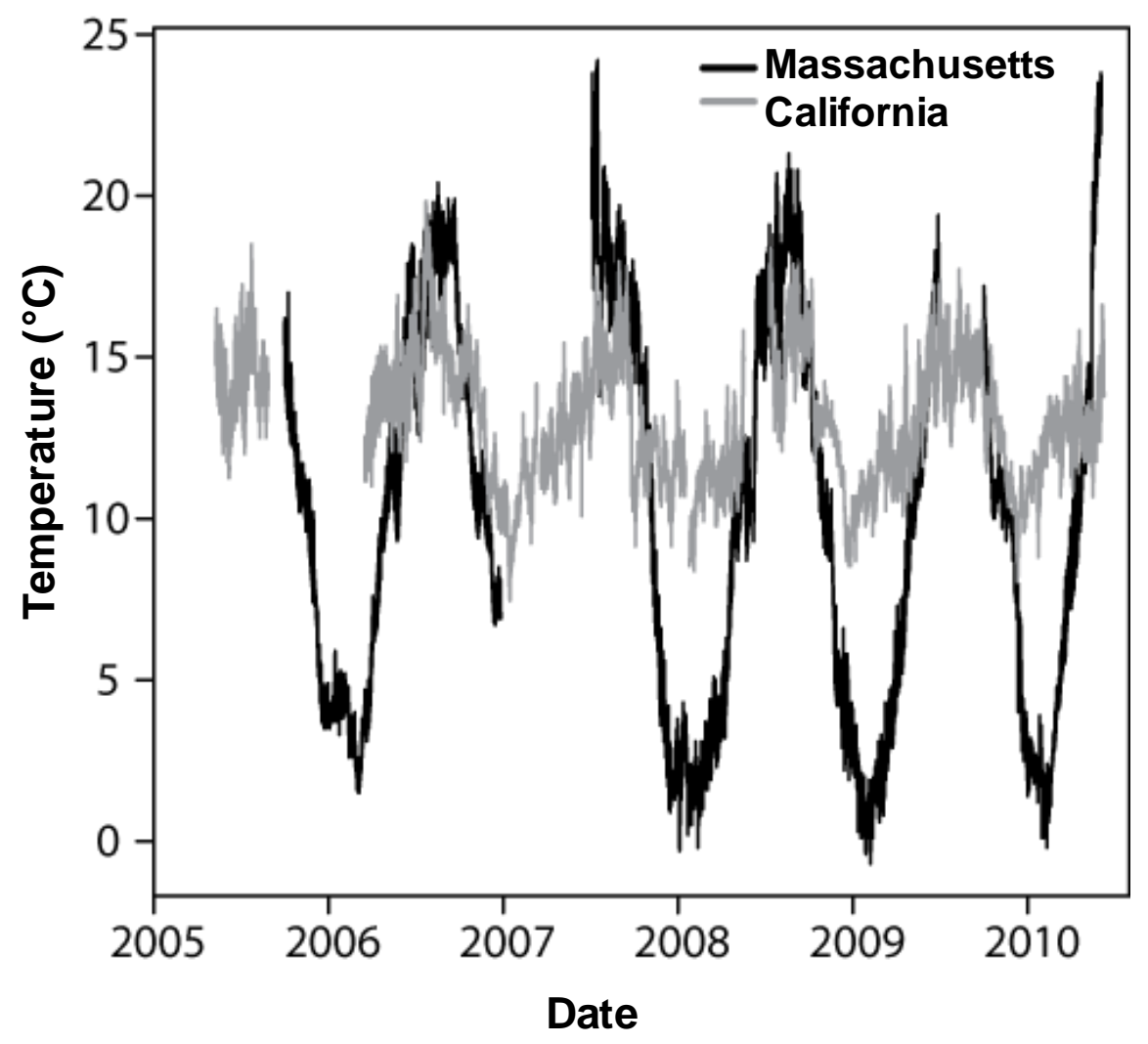

791 
Figure 4.
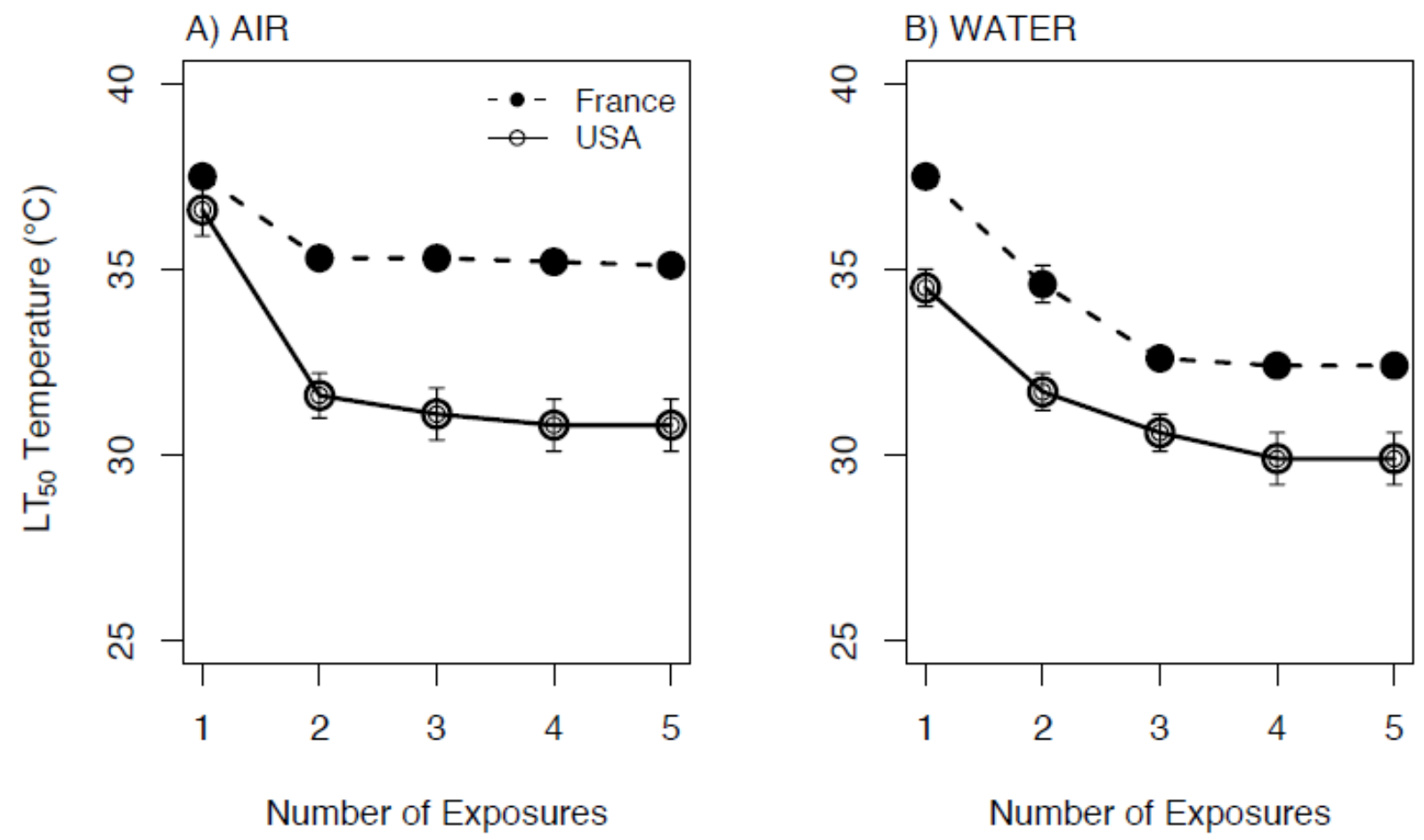

794

795

796

797

798

799

800

801

802

803

804

805

806 
Figure 5 (color, for online version).

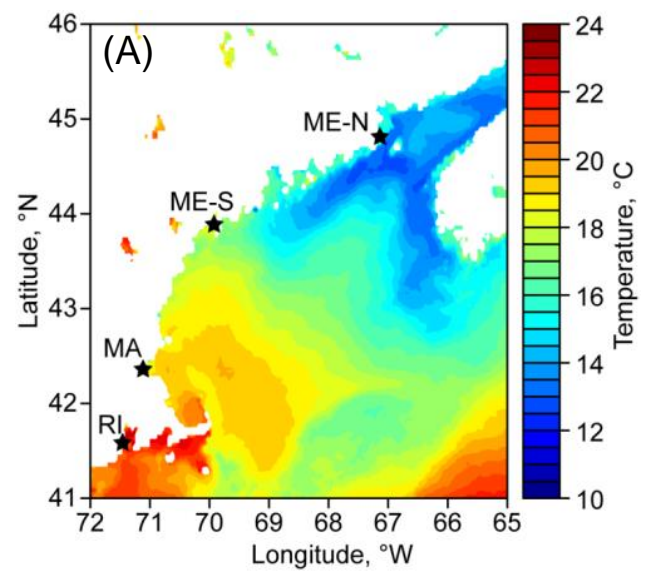

(B) L. obtusata

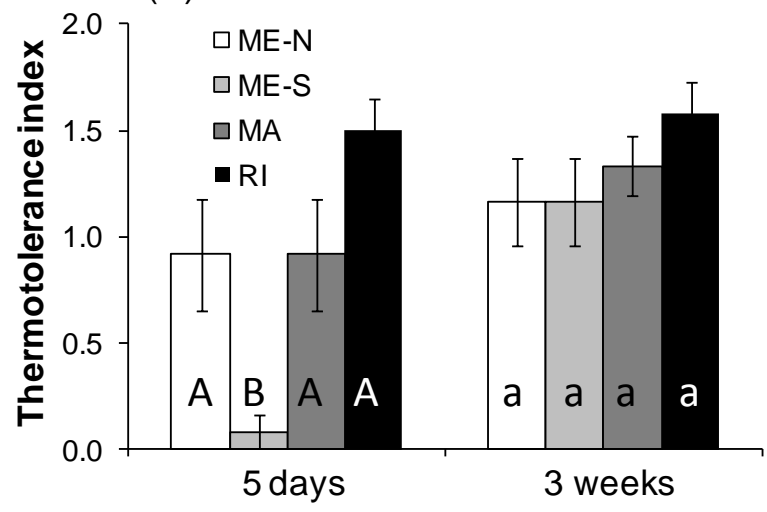

(C) L. littorea

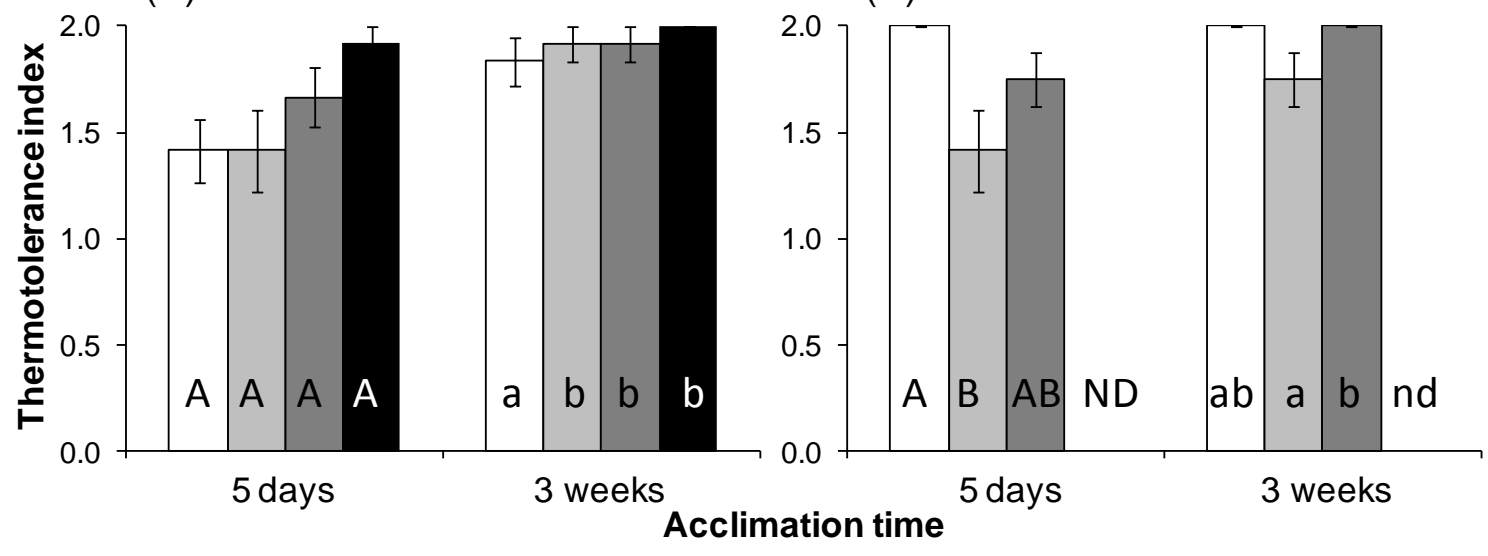

808

809

810 
811 Figure 5 (grayscale, for print version).
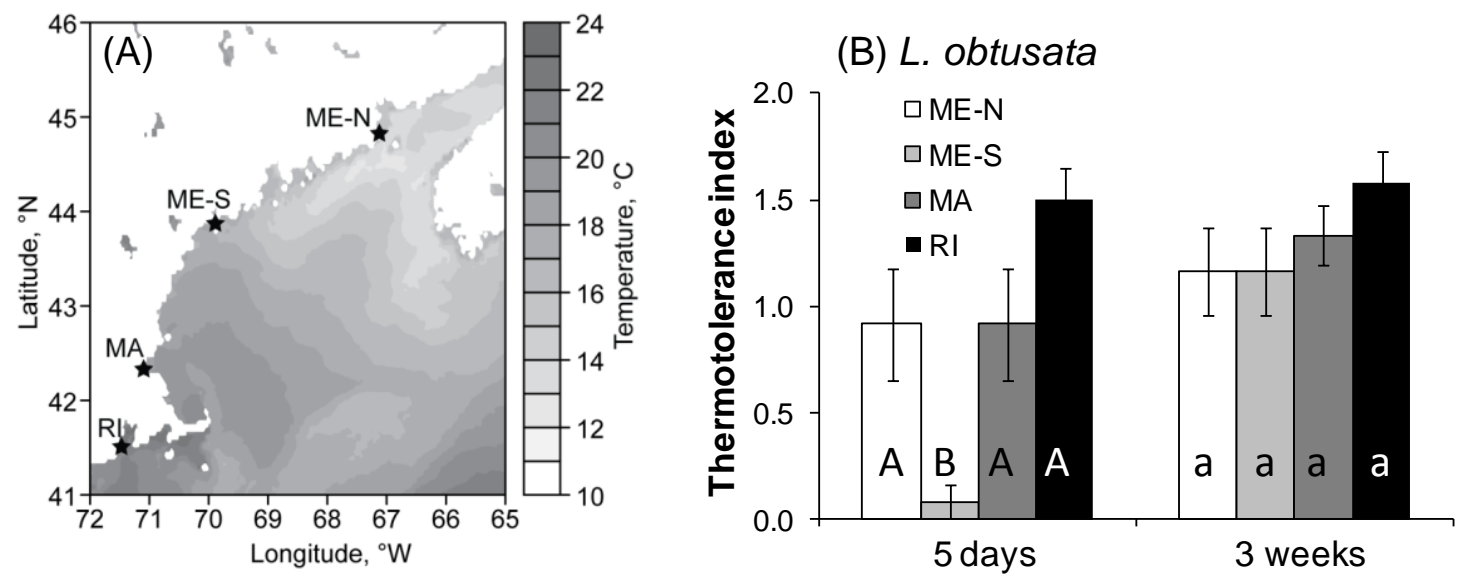

(C) L. littorea
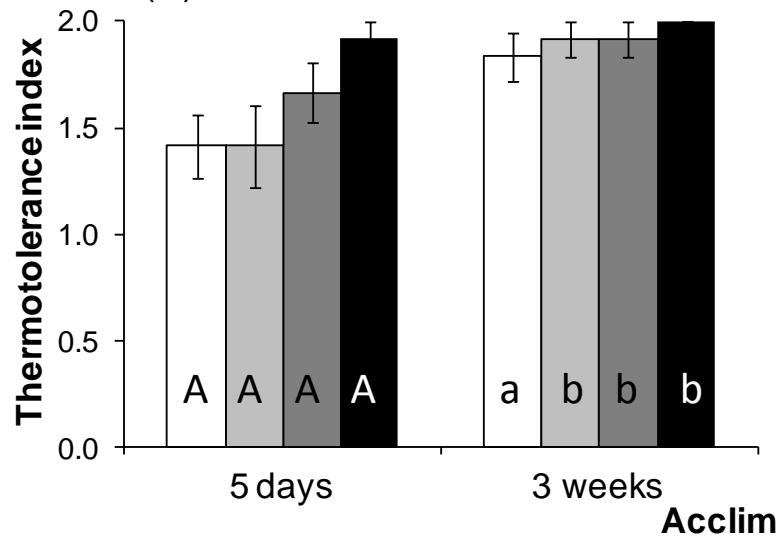

(D) L. saxatilis

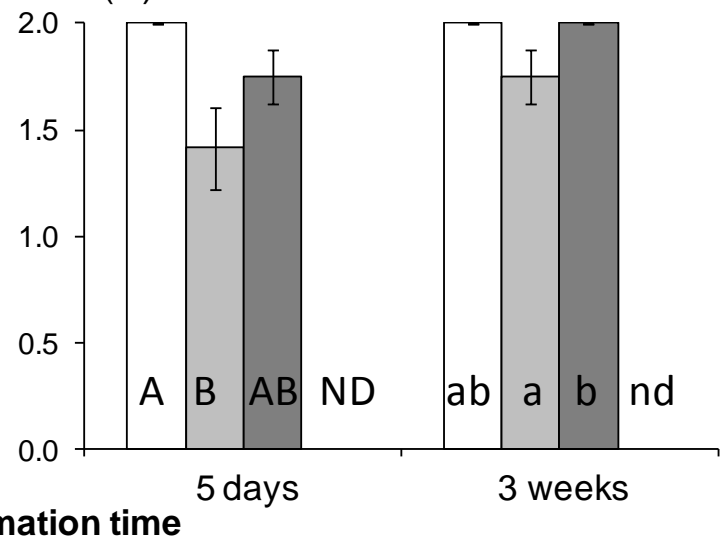

